\title{
Feature Dataset
}

National Cancer Institute

\section{Source}

National Cancer Institute. Feature Dataset. NCI Thesaurus. Code C123884.

A collection of data records from which common expression features can be derived. 